Jurnal Ilmiah Matematika dan Pendidikan Matematika (JMP)

Vol. 11 No. 2, Desember 2019, hal. 59-70

ISSN (Cetak) : 2085-1456; ISSN (Online) : 2550-0422

\title{
KEEFEKTIFAN PEMBELAJARAN MATEMATIKA DENGAN BANTUAN GEOGEBRA PADA MATERI GARIS KELAS VII SMP NEGERI 2 LIMPUNG
}

\author{
Najmah Istikaanah \\ Jurusan Matematika Universitas Jendral Soedirman \\ najmah.mtk@unsoed.ac.id \\ Yeni Setia Liawati \\ SMPN 2 Limpung
}

\begin{abstract}
One of the external obstacles of students is the learning media used by teachers. Learning achievement will be more developed if students actively participate in learning activities. This study aims to improve mathematics learning achievement at line material. The methodology used in this study is an experimental research methodology. The subjects of this study were 7th class students of SMP Negeri 2 Limpung with class VII $A$ as the experimental group and class VII B as the control group. The results showed that the mathematics learning model assisted by Geogebra at line material is effective to be used, this was seen from the completeness of learning outcomes, the influence of reasoning and communication skills to learning achievement with a regression equation $\hat{Y}=36,203+0,591 x$ and a coefficient of determination is $68.7 \%$. Mathematical learning strategies by Geogebra are also better than learning mathematics without Geogebra. Thus Geogebra-assisted learning on line material can be used as an alternative method of learning in order to add the variety of teaching methods in an effort to train students' reasoning and communication skills and increase student learning outcomes..
\end{abstract}

Keywords: effectiveness, Geogebra, experiment.

\begin{abstract}
ABSTRAK. Salah satu hambatan luar dari diri siswa adalah media pembelajaran yang digunakan oleh pengajar. Prestasi belajar akan lebih berkembang apabila siswa ikut serta secara aktif dalam aktivitas belajar. Penelitian ini bertujuan untuk meningkatkan prestasi belajar matematika pada materi garis. Metodologi yang dipakai dalam penelitian ini adalah metodologi penelitian eksperimen. Subyek penelitian ini adalah siswa kelas VII SMP Negeri 2 Limpung dengan kelas VII A sebagai kelompok eksperimen dan kelas VII B sebagai kelompok kontrol. Hasil penelitian menunjukkan bahwa model pembelajaran matematika berbantuan Geogebra pada materi garis efektif untuk digunakan, hal ini terlihat dari ketuntasan hasil belajar, adanya pengaruh keterampilan penalaran dan komunikasi terhadap prestasi belajar dengan persamaan regresi $\hat{Y}=36,203+0,591 x$ dan koefisien determinasi $68,7 \%$. Strategi pembelajaran matematika dengan bantuan Geogebra juga lebih baik dibandingkan pembelajaran matematika tanpa Geogebra. Dengan demikian pembelajaran berbantuan Geogebra pada materi garis dapat dijadikan suatu metode alternatif dalam pembelajaran guna menambah variasi metode mengajar dalam upaya melatih keterampilan penalaran dan komunikasi siswa dan meningkatkan hasil belajar siswa.
\end{abstract}

Kata Kunci: keefektifan, Geogebra, eksperimen. 


\section{PENDAHULUAN}

Salah satu alasan rendahnya minat siswa terhadap matematika karena matematika bersifat abstrak, sehingga perlu perjuangan untuk mempelajarinya. Padahal pelajaran matematika perlu diberikan kepada semua peserta didik mulai dari sekolah dasar untuk membekali peserta didik dengan kemampuan berpikir logis, analitis, sistematis, kritis, dan kreatif, serta kemampuan bekerja sama. Kompetensi tersebut diperlukan agar peserta didik dapat memiliki kemampuan memperoleh, mengelola, dan memanfaatkan informasi untuk bertahan hidup pada keadaan yang selalu berubah, tidak pasti, dan kompetitif. Salah satu materi pada pelajaran Matematika yaitu materi garis-garis sejajar juga bersifat abstrak, sulit untuk dipelajari apalagi kalau menyangkut penalaran dan komunikasi serta pemecahan masalah. Materi garis-garis sejajar merupakan materi yang di dalamnya memuat prinsip dan hitungan.

SMP Negeri 2 Limpung sebagai salah satu SMP di Kabupaten Batang juga tidak luput dari masalah rendahnya minat siswa terhadap pelajaran matematika. SMP Negeri 2 Limpung mempunyai ruang LCD yang cukup memadai, tetapi belum dimanfaatkan secara optimal. Sebagian besar pembelajaran masih dilakukan di dalam kelas dengan metode konvensional yang kurang memaksimalkan penggunaan alat tersebut. Proses belajar mengajar didominasi oleh guru, siswa hanya mendengarkan dan meniru apa yang guru lakukan tanpa ikut terlibat di dalamnya. Dengan pembelajaran yang seperti ini sangat sulit bagi siswa untuk menyerap materi yang disampaikan apalagi untuk materi garis.

Untuk mengatasi masalah tersebut maka perlu dilakukan inovasi pembelajaran agar siswa lebih tertarik, tidak bosan, dan lebih cepat menangkap materi yang diberikan. Salah satu media pembelajaran yang bisa membantu siswa untuk menvisualisasikan materi garis yang bersifat abstrak adalah media dengan software Geogebra. Media dengan software Geogebra ini digunakan untuk menyampaikan materi dalam pembelajaran. Dengan bantuan Geogebra diharapkan dapat memotivasi siswa untuk belajar karena Geogebra ini dibuat semenarik mungkin dengan menampilkan aspek visual yang menjadi pondasi materi garis. Dengan Geogebra ini memungkinkan siswa untuk mempelajari 
materi dalam suasana yang menyenangkan sehingga siswa tidak bosan. Prayito, Saputro, dan Nursyahidah (2014) menyatakan bahwa media pembelajaran Geometri SMP dengan bantuan Geogebra dapat meningkatkan kemampuan penalaran dan pemecahan masalah matematis.

Berdasarkan uraian diatas dapat dirumuskan masalah sebagai berikut :

1. Apakah pembelajaran matematika berbantuan Geogebra pada materi garis dapat mencapai ketuntasan belajar?

2. Apakah keterampilan penalaran dan komunikasi pada pembelajaran matematika berbantuan Geogebra berpengaruh terhadap peningkatan prestasi belajar siswa?

3. Apakah prestasi belajar kelas dengan pembelajaran matematika dengan bantuan Geogebra lebih baik daripada kelas dengan strategi konvensional?

\section{METODE PENELITIAN}

Penelitian ini merupakan penelitian eksperimen yang diawali dengan menentukan populasi dan memilih sampel dari populasi yang sudah ada. Adapun pola rancangan yang digunakan sebagai berikut.

Tabel 2.1. Prosedur Penelitian

\begin{tabular}{l|c|c|c|}
\hline \multicolumn{1}{|c|}{ Kelompok } & Perlakuan & Posttest \\
\cline { 2 - 4 } & Kelompok Eksperimen & $\mathrm{X}$ & Tes \\
\hline Kelompok Kontrol & $\mathrm{Y}$ & Tes \\
\hline & \\
Keterangan : & :Model pembelajaran kooperatif berbantuan Geogebra \\
$\mathrm{Y} \quad$ : Pembelajaran dengan metode ekspositori
\end{tabular}

Populasi pada penelitian ini adalah siswa kelas VII SMP Negeri 2 Limpung, sebanyak 6 kelas yang berjumlah 190 siswa. Sampel yang diambil dalam penelitian ini adalah kelas VII A sebagai kelas kontrol dan kelas VII B sebagai kelas eksperimen.

\section{Metode Pengumpulan Data :}

1. Metode Dokumentasi 
Metode dokumentasi digunakan untuk memperoleh data yang telah ada yaitu nilai ulangan matematika pada materi sebelumnya. Metode ini digunakan untuk mengumpulkan data kemampuan awal siswa yang menjadi sampel penelitian. Data yang diperoleh dianalisis untuk menentukan normalitas dan homogenitas antara kelas eksperimen dan kelas kontrol dalam sekolah.

2. Metode Tes

Data dikumpulkan dengan menggunakan teknik tes, teknik tes dalam penelitian ini dilakukan setelah perlakuan diberikan kepada kelas dengan strategi course review horay yang didukung CD interaktif sebagai kelas eksperimen dan kelas dengan pembelajaran konvensional sebagai kelas kontrol dengan tujuan untuk mendapatkan data akhir. Tes ini diberikan kepada kedua kelas dengan alat tes yang sama.

3. Metode Observasi

Metode ini digunakan untuk mengukur keterampilan penalaran dan komunikasi. Observasi dilakukan hanya pada kelas eksperimen.

\section{Analisis Perangkat Tes :}

Untuk menganalisis perangkat digunakan validitas, reliabilitas, taraf kesukaran dan daya beda.

\section{Analisis Data :}

1. Analisis Data Tahap Awal
a. Uji Normalitas
b. Uji Kesamaan Dua Varian (homogenitas)
c. Uji Kesamaan Dua Rata-Rata (Dua Pihak)

2. Analisis Data Tahap Akhir

a. Pembelajaran matematika berbantuan Geogebra dapat mencapai ketuntasan belajar.

1) Uji Normalitas Sampel

2) Uji Rata-rata dua pihak

Berdasarkan kriteria ketuntasan belajar matematika di SMP Negeri 2 Limpung, belajar dikatakan tuntas jika memenuhi syarat 
ketuntasan belajar yaitu rata-rata hasil belajar mencapai minimal 65. Disini kita akan menggunakan uji $t$ dua pihak.

a) Uji ketuntasan keterampilan penalaran dan komunikasi

$\mathrm{H}_{\mathrm{o}}: \mu=75$

Hi : $\mu_{1} \neq 75$

b) Uji ketuntasan prestasi belajar

$\mathrm{H}_{\mathrm{o}}: \mu=65$

Hi : $\mu_{1} \neq 65$

Rumus yang digunakan adalah :

$$
t=\frac{\bar{x}-\mu_{o}}{\frac{s}{\sqrt{n}}}
$$

Kriteria pengujian didapat dari daftar distribusi student $t$ dengan $d k=(n-1)$ dan peluang $\left(1-\frac{1}{2} \alpha\right)$. Jadi terima Ho jika $-t_{1-\frac{1}{2} \alpha}<t<t_{1-\frac{1}{2} \alpha}$ dan tolak $\mathrm{H}_{\mathrm{o}}$ dalam hal lainnya.

Keterangan:

$$
\begin{aligned}
& \bar{X}=\text { rata-rata hasil belajar } \\
& \mu_{\mathrm{o}}=75 \text { dan } 65 \\
& \mathrm{~s}=\text { simpangan baku } \\
& \mathrm{n}=\text { jumlah siswa }
\end{aligned}
$$

(Sudjana, 2002: 227)

b. Keterampilan penalaran dan komunikasi berpengaruh terhadap peningkatan prestasi kelas dengan strategi course review horay yang didukung CD interaktif.

1) Uji Normalitas Sampel

2) Regresi
a) Uji kelinieran regresi
b) Uji independen/ keberartian arah regresi
c) Uji heteroskedastisistas

3) Uji lanjut regresi (korelasi) 
c. Prestasi kelas dengan strategi course review horay yang didukung CD interaktif lebih baik daripada kelas dengan pembelajaran konvensional.

1) Uji Normalitas Sampel

2) Uji Kesamaan Dua Varian (homogenitas)

3) Uji Kesamaan Dua Rata-Rata (Dua Pihak)

\section{HASIL DAN PEMBAHASAN}

Berdasarkan penelitian yang telah dilakukan, diperoleh data hasil penelitian. Data ini kemudian dianalisis untuk mendapatkan kesimpulan dari hasil penelitian. Analisis data pada penelitian ini terdiri dari dua tahap, yaitu analisis data tahap awal dan analisis data tahap akhir.

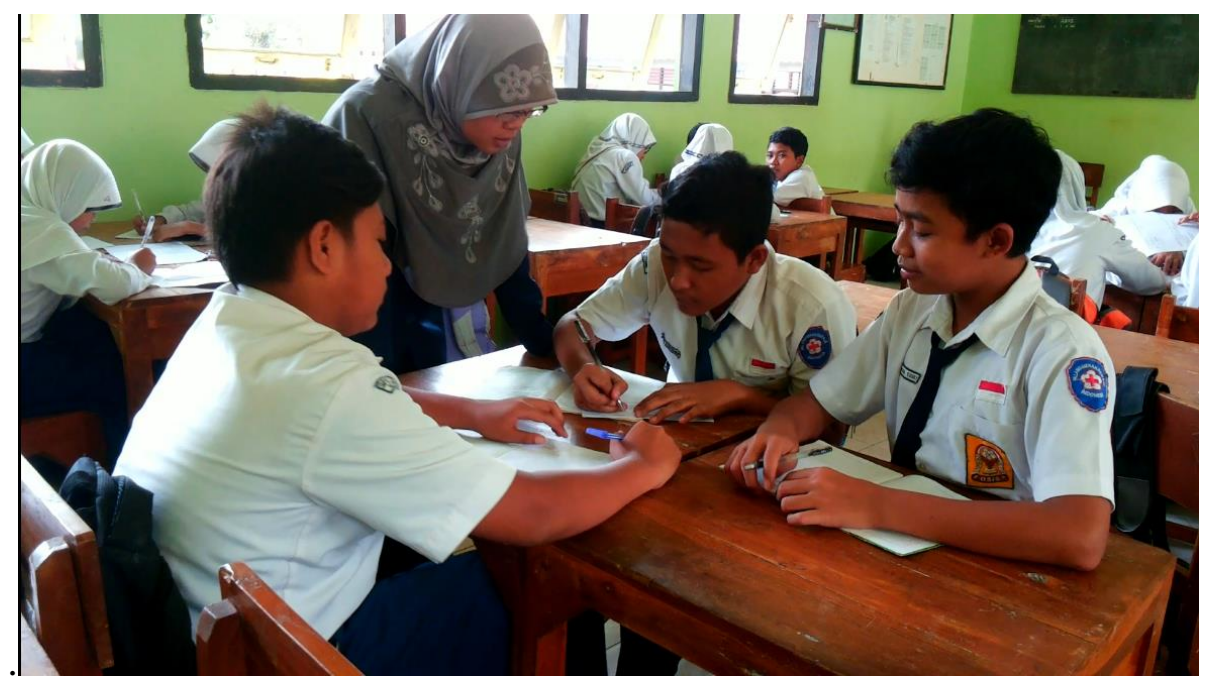

Gambar 31 Proses pembelajaran di kelas

\section{Analisis Data Tahap Awal :}

Analisis pada tahap awal meliputi tiga langkah yaitu sebagai berikut.

a. Uji Normalitas

$$
\begin{aligned}
& \mathrm{H}_{\mathrm{o}} \text { : data berdistribusi normal } \\
& \mathrm{H}_{i} \text { : data tidak berdistribusi normal }
\end{aligned}
$$

Uji normalitas digunakan untuk mengetahui apakah sampel berasal dari populasi yang berdistribusi normal. Dari hasil uji normalitas pada kelas VII A, diperoleh $\chi^{2}$ hitung $=3,75$ sedangkan dari 
distribusi chi-kuadrat dengan signifikasi $5 \%$ dan $\mathrm{dk}=3$ diperoleh harga $\chi^{2}$ tabel $=7,81$. Sehingga diperoleh $\chi^{2}{ }_{\text {hitung }}<\chi^{2}$ tabel. Karena $\chi^{2}$ hitung $<\chi_{\text {tabel }}^{2}$ maka dapat disimpulkan bahwa kelas VII A berasal dari populasi yang berdistribusi normal.

Uji normalitas pada kelas VII B diperoleh $\chi^{2}$ hitung $=5,78$, sedangkan dari distribusi chi kuadrat dengan signifikasi 5\% dan $\mathrm{dk}=3$ diperoleh harga $\chi^{2}$ tabel $=7,81$. Sehingga diperoleh $\chi^{2}{ }_{\text {hitung }}<\chi^{2}$ tabel. Karena $\chi^{2}{ }_{\text {hitung }}<\chi^{2}$ tabel maka dapat disimpulkan bahwa kelas VII D berasal dari populasi yang berdistribusi normal.

b. Uji Kesamaan Dua Varian (Homogenitas)

Uji homogenitas digunakan untuk mengetahui apakah sampel yang diambil berasal dari populasi dengan varian yang homogen. Untuk menguji homogenitas varian digunakan uji Hartley Pearson. Berikut ini disajikan data varian dua kelas.

$$
\begin{aligned}
& \text { Ho: } \sigma_{1}^{2}=\sigma_{2}^{2} \\
& \text { Hi : } \sigma_{1}^{2} \neq \sigma_{2}{ }^{2}
\end{aligned}
$$

Tabel 3.1 Nilai Varian Tiap Kelas

\begin{tabular}{|c|c|c|}
\hline Kelas & Banyaknya siswa (n) & Varians \\
\hline VII A & 32 & 88.7966 \\
\hline VII B & 32 & 107,1728 \\
\hline
\end{tabular}

Dari perhitungan diperoleh $F_{\text {hitung }}=1,207$. Dengan $\alpha=5 \%$, dari daftar distribusi $\mathrm{F}$ dengan $\mathrm{v} 1=31$ dan $\mathrm{v} 2=31$ didapat $F_{\text {tabe }} \mathrm{l}=$ $F_{(0,025)(37,37)}=1,92$. Sehingga didapat $F_{\text {hitung }}<F_{\text {tabel }}$. Karena $F_{\text {hitung }}<$ $F_{\text {tabel }}$ maka hipotesis Ho diterima. Sehingga dapat disimpulkan varians dari kedua kelas homogen.

c. Uji Kesamaan Dua Rata-rata

Uji beda rata-rata pada penelitian ini digunakan untuk mengetahui apakah kelas eksperimen dan kelas kontrol mempunyai 
rata-rata yang sama. Untuk menguji beda rata-rata digunakan uji t dua pihak.

$$
\begin{aligned}
& \mathrm{H}_{\mathrm{o}}: \mu_{1}=\mu_{2} \\
& \mathrm{H}_{\mathrm{i}}: \mu_{1} \neq \mu_{2}
\end{aligned}
$$

Dari perhitungan diperoleh $t_{\text {hitung }}=0,846$. Dengan $\alpha=5 \%$, dari daftar distribusi $\mathrm{t}$ dengan $\mathrm{dk}=74$ didapat $t_{\text {tabe }} \mathrm{l}=\mathrm{t}_{(0,975)(74)}=1,99$. Sehingga didapat $t_{\text {hitung }}<t_{\text {tabel. }}$. Karena $t_{\text {hitung }}<t_{\text {tabel }}$ maka hipotesis Ho diterima. Sehingga dapat disimpulkan kelas eksperimen dan kelas kontrol mempunyai rata-rata yang sama.

Dari uji normalitas, uji homogenitas dan uji beda dua rata-rata diperoleh suatu kesimpulan bahwa kelas eksperimen dan kelas kontrol layak/signifikan digunakan sebagai sampel dalam penelitian ini karena berangkat dari titik awal yang sama.

\section{Analisis Data Tahap Akhir :}

Dari hasil analisis data diperoleh rata-rata keterampilan penalaran dan komunikasi 75,87 dan rata-rata prestasi belajar 81,04. Berdasarkan uji kesamaan dua rata-rata dua pihak dengan menggunakan patokan minimal tuntas 75 untuk keterampilan penalaran dan komunikasi diperoleh $t_{\text {hitung }}=0,5$ dan $t_{\text {tabel }}=2,03$. Karena $-t_{\text {tabel }}<t_{\text {hitung }}<t_{\text {tabel }}$ maka $\mathrm{H}_{\mathrm{o}}$ diterima, hal ini berarti keterampilan penalaran dan komunikasi telah mencapai ketuntasan. Berdasarkan uji kesamaan dua pihak untuk uji ketuntasan prestasi belajar dengan menggunakan standar minimal tuntas dari SMP Negeri 2 Limpung yaitu 65, diperoleh $t_{\text {hitung }}=10,98$ dan $t_{\text {tabel }}=2,03$. Karena $t_{\text {hitung }}>t_{\text {tabel }}$ maka Ho ditolak yang berarti rata-rata nilai prestasi belajar $\neq 65$ yang mempunyai kemungkinan $<65$ atau $>65$. Dengan melihat rata-rata nilai prestasi belajar yaitu 81,04 maka dapat disimpulkan bahwa nilai prestasi belajar $>65$ atau telah mencapai ketuntasan belajar. 


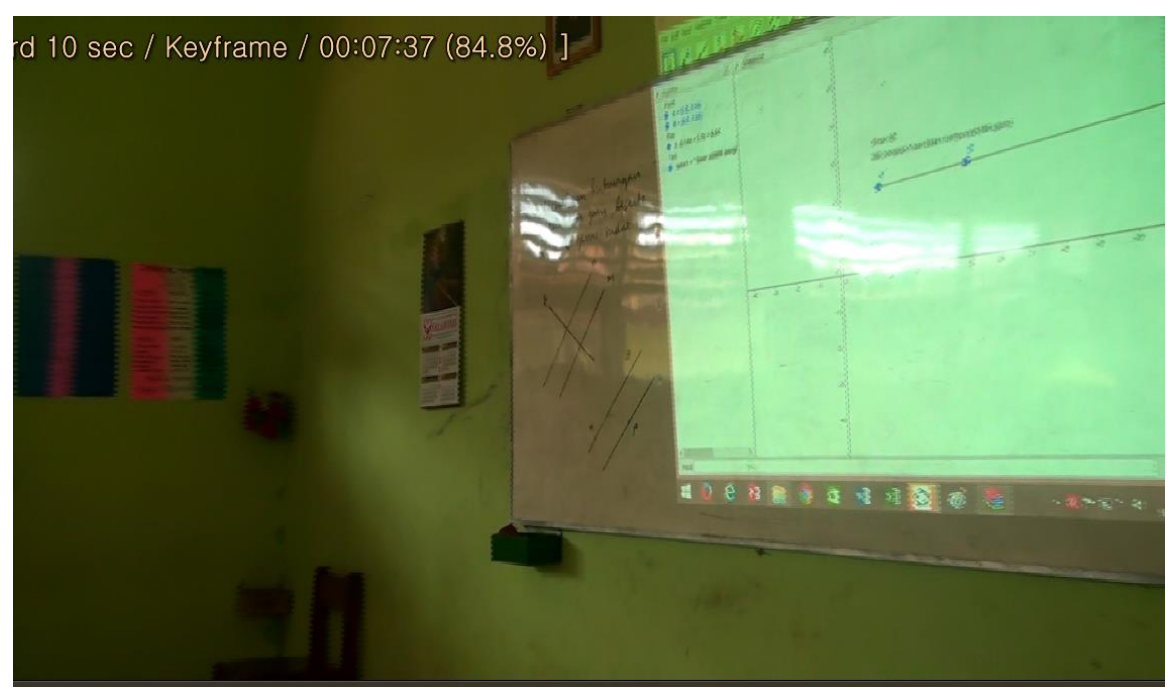

Gambar 3.2 Penggunaan Geogebra pada materi garis

Pada pembelajaran kelas eksperimen keterampilan penalaran dan komunikasi siswa lebih ditekankan pada pembelajaran kooperatif dengan bantuan Geogebra. Dengan adanya keterampilan penalaran dan komunikasi tersebut akan menumbuhkan motivasi belajar yang tinggi pada siswa yang pada akhirnya berpengaruh terhadap prestasi belajar siswa. Terdapat korelasi cukup tinggi antara keterampilan penalaran dan komunikasi terhadap hasil belajar yaitu 0,829. Angka korelasi yang positif menunjukkan semakin besar keterampilan penalaran dan komunikasi akan membuat nilai prestasi belajar cenderung meningkat. Persamaan regresi yang diperoleh dari analisis data adalah $\hat{Y}=36,203+0,591 x$ dan koefisien determinasi sebesar $68,7 \%$. Pada uji heteroskedastisitas terlihat bahwa nilai eror berada di sekitar nol dan tidak membentuk suatu pola tertentu, ini berarti tidak terjadi heteroskedasti atau residual memiliki varian yang konstan. Koefisien determinasi sebesar $68,7 \%$ yang artinya $68,7 \%$ prestasi belajar siswa dipengaruhi oleh keterampilan penalaran dan komunikasi sedangkan 31,3\% dipengaruhi oleh hal yang lain.

Rata-rata prestasi belajar untuk kelas eksperimen adalah 81,04 dan kelas kontrol 70,82. Berdasarkan hasil dari analisis statistik pada data tahap akhir, tepatnya pada uji kesamaan dua rata-rata dua pihak diperoleh $t_{\text {hitung }}=5,112$ dan $t_{\text {tabel }}=1,99$. Karena $t_{\text {hitung }}>t_{\text {tabel }}$ maka Ho ditolak dan Hi diterima yang artinya 
rata-rata prestasi belajar kelompok eksperimen $\neq$ rata-rata prestasi belajar kelompok kontrol. Dengan melihat rata-rata prestasi belajar dari kedua kelas di mana rata-rata prestasi belajar kelompok eksperimen lebih besar dari rata-rata prestasi belajar kelompok kontrol maka dapat ditarik kesimpulan bahwa rata-rata prestasi belajar kelompok eksperimen lebih baik dibandingkan rata-rata prestasi kelompok kelas kontrol.

Pembelajaran matematika berbantuan Geogebra pada kelas eksperimen memiliki peningkatan hasil belajar yang lebih tinggi daripada kelompok kontrol, hal ini terjadi karena adanya penggunaan suatu media pembelajaran berupa software Geogebra. Geogebra sangat berguna bagi guru dan siswa. Bagi guru alat ini mempermudah dalam penyampaian materi pembelajaran dan bagi siswa meningkatkan rutinitas belajar siswa di rumah serta menjadikan siswa tahu apa yang akan disampaikan guru di sekolah.

Sesuai dengan apa yang dikemukakan Maningrum (2007) bahwa kalau dalam belajar siswa dapat diberi pengalaman langsung (melalui media, demonstrasi, "fields trip", dramatisasi), maka situasi pengajarannya itu akan meningkatkan kegairahan dan minat siswa tersebut dalam belajar. Hal ini sejalan dengan pendapat Heinich, Molenda, Russel and Smaldino (2002) yang menyatakan bahwa media pengajaran dalam membelajarkan dapat mengkonkritkan ide-ide atau gagasan yang bersifat konseptual, sehingga mengurangi kesalahpahaman siswa dalam mempelajari dan memberikan pengalaman-pengalaman yang nyata yang merangsang aktivitas diri sendiri untuk belajar, sehingga siswa tergugah untuk melakukan kegiatan belajar, yang pada akhirnya berpengaruh terhadap hasil belajar siswa.

Secara umum hasil penelitian menunjukkan bahwa pembelajaran matematika berbantuan Geogebra pada materi garis lebih efektif, hal ini bisa diketahui dari hasil belajar (keterampilan penalaran dan komunikasi dan prestasi belajar) kelompok eksperimen yang telah tuntas, adanya pengaruh keterampilan penalaran dan komunikasi terhadap prestasi belajar siswa, dan hasil belajar kelas eksperimen yang lebih baik dari kelas kontrol. 


\section{KESIMPULAN DAN SARAN}

Pembelajaran matematika berbantuan Geogebra sudah efektif karena :

a. Hasil belajar (keterampilan penalaran dan komunikasi dan prestasi belajar) matematika untuk materi garis dengan pembelajaran matematika berbantuan Geogebra telah mencapai ketuntasan belajar

b. Keterampilan penalaran dan komunikasi memiliki pengaruh terhadap prestasi belajar terlihat dari hasil perhitungan regresi dengan persamaan $\hat{Y}$ $=36,203+0,591 x$ koefisien korelasi 0,829 dan koefisien determinasi $68,7 \%$. Koefisien determinasi $68,7 \%$ artinya prestasi belajar siswa dipengaruhi oleh keterampilan penalaran dan komunikasi sebesar 68,7\%.

c. Prestasi belajar matematika untuk materi garis dengan pembelajaran matematika berbantuan Geogebra lebih baik dibandingkan pembelajaran matematika tanpa Geogebra.

\section{UCAPAN TERIMAKASIH}

Ucapan terimakasih diberikan kepada banyak pihak yang telah banyak memberikan bantuan dan dukungannya sehingga artikel penelitian ini dapat terselesaikan.

\section{DAFTAR PUSTAKA}

Adinawan, M. C. dan Sugijono, Matematika untuk SMP kelas VII, Erlangga, Jakarta, 2014.

Arsyad, A., Media pembelajaran, Raja Grafindo Persada, Jakarta, 2005.

Arifin, Z., Evaluasi Instruksional, Depdiknas, Bandung, 1991.

Arikunto, S., Prosedur Penelitian Suatu Pendekatan Praktek, Rineka Cipta, Jakarta, 1997.

Dasar-dasar Evaluasi Pendidikan, Rineka Cipta, Jakarta, 2003.

Cunayah, C., Kompetensi Matematika untuk SMP/MTs Kelas VII Semester 1 dan 2, Yrama Widya, Bandung, 2005. 
Heinich, R., Molenda, M., Russel, J. D., dan Smaldino, S.E., 2002. Instructional Media and Technology For Learning, $7^{\text {th }}$ Edition., Prentice Hall Inc., New Jersey, 2002.

Maningrum, L., Keefektifan Pendekatan PAKEM dengan Media CD Pembelajaran dalam Pembelajaran Matematika Sub Materi Pokok Keliling dan Luas Lingkaran pada Siswa Kelas VII SMP Panguri Luhur Giriwoyo Wonogiri, Skripsi, Universitas Negeri Semarang, 2007.

Manthovani, S., Pelaksanaan KTSP di SMA Nasional Karangturi Semarang (Strategi dan implementasi), Seminar Nasional Pendidikan Universitas Negeri Semarang, 2007.

Prayito, Saputro, dan Nursyahidah, Pengembangan Media Pembelajaran Geometri SMP Dengan Pendekatan Pendidikan Matematika Realistik Berbasis Geogebra Untuk Meningkatkan Kemampuan Penalaran Dan Pemecahan Masalah Matematis, Perpustakaan Universitas PGRI Semarang, 2014.

Sobel, M. dan Maletsky, E., Mengajar Matematika Sebuah Buku Sumber Alat Peraga, Aktivitas, dan Strategi, PT. Gelora Aksara Pertama, Jakarta, 2003. Sudjana, Metoda Statistika, Edisi ke-6, Tarsito, Bandung, 2002.

Sugandhi, Achmad, dan Haryanto, Teori Pembelajaran, UPT MKK UNNES, Semarang, 2004. 